DOI: $10.17516 / 1997-1370-0797$

УДК 93/94

\title{
Socio-Cultural Appearance of Employees of the Lower Soviet Administrative Apparatus of Eastern Siberia in the First Half of the 1920s
}

\author{
Tat'iana G. Karchaeva* \\ Siberian Federal University \\ Krasnoyarsk, Russian Federation
}

Received 24.01.2021, received in revised form 21.03.2021, accepted 06.07.2021

\begin{abstract}
The study tested members of volost executive committees, deputies, chairmen and secretaries of village Soviets that served in the Yeniseisk and Irkutsk Governates from 1921 till 1925. Village Soviets were meetings of deputies elected to fulfill people's right to power. Volost executive committees were administrative and executive public service for village Soviets. In accordance with archival materials, we determined that 1,357 village Soviets worked in the Yenisesk Governate in 1923 (including Achinsk, Yeniseisk, Kansk, Krasnoyarsk, Minusinsk, Turukhansk uyezds). 782 inhabitants and 1.9 villages formed one village Soviet in the Yeniseisk Governate of several members. On average, one village Soviet included 4-5 members. The number of residents in one village of the Yeniseisk Governate was 404, and 7,071 people lived in one volost. Moreover, 9 village Soviets formed one volost executive committee of 41 members. 460 village Soviets were located in the Irkutsk Governate in 1923(including sparsely populated Balagansky, Selenginsky, Kirensky, Ziminsky, Verkholensky, Irkutsk, Tulunsky uyezds). Therefore, one volost Executive Committee included 32 members. 256 people lived in one village in the Irkutsk Governate; 6,839 inhabitants lived in one volost. Socio-cultural image of employees in the Yeniseisk Governate's volost Executive Committees was not an elite image: $64 \%$ communists; $83 \%$ peasants; $17 \%$ workers and intellectuals; $2.4 \%$ had a higher education level; $67 \%$ had secondary education level; $30 \%$ had primary education level; $0.6 \%$ had a home education level; however, there weren't any illiterates. The Irkutsk Governate's volost Executive Committees included: 37 \% communists; 85 \% peasants; $15 \%$ workers and intellectuals; $99 \%$ had higher, secondary and primary education levels. However, members of village Soviets were more democratic than members of volost Executive Committees. For example, $15 \%$ of village Soviets' deputies were illiterate in the Yeniseisk Governate. Moreover, $16 \%$ of deputies were illiterate in the Irkutsk Governate. Other deputies had lower and home education level. Only $11 \%$ of village Soviets' deputies were communists in the Yeniseisk Governate. $9 \%$ of deputies were communists in the village Soviets in the Irkutsk Governate. Importantly, $99 \%$ were men among local administrators in Eastern Siberia. Although gender equality was proclaimed in Soviet Russia, it was absent in the Yeniseisk and Irkutsk Governates in the first half of
\end{abstract}

(C) Siberian Federal University. All rights reserved

* Corresponding author E-mail address: tg.karchaeva@gmail.com ORCID: 0000-0002-9705-7921 
the 1920s. As a result, members of the volost executive committees and village Soviets in Eastern Siberia were ordinary people. They did not have any professional experience; and they had a low level of work ethics. To analyze the information about members of volost Executive Committees, deputies, chairmen and secretaries of village Soviets we used archival materials of the Fund No. 393 «People's Commissariat of Internal Affairs of the RSFSR» from the State Archives of the Russian Federation (Moscow).

Keywords: concrete historical research; statistics; public councils; village Soviets; executive committees; public service; public participation; Yeniseisk Governate; Irkutsk Governate; Eastern Siberia; Soviet Union.

Research area: history.

Citation: Karchaeva, T.G. (2021). Socio-cultural appearance of employees of the lower soviet administrative apparatus of eastern siberia in the first half of the 1920s. J. Sib. Fed. Univ. Humanit. soc. sci., 14(8), 1219-1230. DOI: 10.17516/1997-1370-0797.

\title{
Социокультурный облик служащих низового советского аппарата управления Восточной Сибири в первой половине 1920-х гг.
}

\author{
Т.Г. Карчаева \\ Сибирский федеральньй университет \\ Российская Федерачия, Красноярск
}

\begin{tabular}{l}
\hline Аннотация. В ходе исследования были изучены биографии членов волостных \\
исполнительных комитетов и сельских Советов, служившие в Енисейской \\
и Иркутской губерниях в первой половине 1920 -х гг. В постреволюцинной \\
России сельские Советы представляли собой созываемые собрания депутатов, \\
избранных сельчанами для реализации их права на власть, при этом волостные \\
исполнительные комитеты были распорядительными и исполнительными \\
органами сельских Советов. На основе архивных данных установлено, что в 1923 г. \\
было 1357 сельских Советов в Енисейской губернии (в Ачинском, Енисейском, \\
Канском, Красноярском, Минусинском, Туруханском уездах). В данном регионе \\
один сельский Совет формировался в среднем 782 жителями, то есть 1,9 \\
селениями, и в него входили 4.5 члена. При этом на одно селение в Енисейской \\
губернии приходилось 404 жителя, на одну волость - 7071 , на один волостной \\
исполнительный комитет - 9 Сельсоветов и 41,3 членов Сельсоветов. В свою \\
очередь, в менее населенных Балаганском, Селенгинском, Киренском, Зиминском, \\
Верхоленском, Иркутском, Тулунском уездах Иркутской губернии в 1923 г. было \\
460 сельских Советов, на один волостной Исполнительный комитет приходилось \\
32,0 членов Сельсоветов, на одно селение и одну волость - 256 и 6839 жителей \\
соответственно. Социокультурный облик служащих волостных исполнительных \\
комитетов Енисейской губернии был представлен следующими характеристиками: \\
коммунисты - 64 \%; работали в сельском хозяйстве 83 \%; высшее образование \\
имели $2,4 \%$ с среднее образование - $67 \%$ начальное образование - $30 \%$,
\end{tabular} 
домашнее - 0,6\%, неграмотные отсутствовали. Среди служащих волостных исполнительных комитетов Иркутской губернии коммунистами были $37 \%$; сельским хозяйством занимались $85 \%$; высшее, среднее и начальное образование имели более 99 \% служащих. Следует отметить, что состав членов сельских Советов, по данным 1923 г., был более демократичен, чем кадровый состав Волисполкомов. Так, в Енисейской и Иркутской губерниях неграмотными были 15 и $16 \%$ членов Сельсоветов соответственно, а остальные 85 и $84 \%$ имели преимущественно низшее и домашнее образование, при этом коммунистами были всего $11 \%$ и $9 \%$ - депутатами. Несмотря на провозглашенное в Советской России гендерное равенство, почти $99 \%$ местных управленцев в Восточной Сибири это мужчины. Следовательно, на примере Иркутской и Енисейской губерний доказано, что члены волостных Исполнительных комитетов и сельских Советов в первой половине 1920-х гг. не были представителями элитарных слоев общества. Однако среди членов волостных Исполнительных комитетов было больше грамотных и коммунистов, чем в сельских Советах. Анализ источников произведен с использованием статистических методов.

Ключевые слова: конкретно историческое исследование, статистика, общественные советы, сельсоветы, исполнительные комитеты, государственная служба, политическое участие, Енисейская губерния, Иркутская губерния, Восточная Сибирь, Советский Союз.

Научная специальность: 07.00. 00 - исторические науки и археология.

\section{Введение}

На современном этапе гуманитарной науки междисциплинарность стала одним из признаков исторического знания. Активный диалог истории, антропологии, социологии, политологии, математики, информатики и прочих наук обрел новую жизнь. Зарубежные научные центры уже много лет предпринимают попытки проиллюстрировать облик государственных служащих советской России с позиции антропологии. Заинтересованность в этом иностранных историков обусловлена необходимостью познания социализма как цивилизационной вариативности развития общества.

В 1980-е гг. учеными Национального центра научных исследований во Франции (C.N.R.S. - Centre National de la Recherche Scientifique, France) рассмотрена эволюция кадрового состава судебных органов СССР в период правления И.В. Сталина (Rittersporn, 1984: 211-237). Антропологический подход был использован американскими учеными для характеристики российских «чиновников» в период Гражданской войны (1917-1920 гг.) и в другие годы эпохальных событий российской истории (Cook, 2013: 1-31; Hahn, 1988: 5-25). Сравнительный анализ управленческих традиций в Российской империи, Советском Союзе и Российской Федерации уже осуществлен американскими учеными Государственного исследовательского университета в Боулинг-Грин штата Огайо (BGSU - Bowling Green State University in Ohio, USA) (Rowney, 2009: 3-9). Однако территориальная удаленность от исторических источников российских региональных архивов и библиотек позволяет отечественным ученым опережать зарубежных коллег в этом направлении.

В 1990-2010-е гг. российские историки переориентировали свое внимание с общественных отношений на личность. Тематика истории чиновничества на уровне регионов разработана и продолжает разрабатываться в Иркутске, Красноярске, Новосибирске, Екатеринбурге и других городах современной России (Vladimirov, Sarafanov, Shchetinina, 2019: 99-105; Dameshek L., Dameshek I., 2020: 103-107; Dyatlov, Dyatlova, 2020: 623-638; Kazarin, 2020: 
101-106; Mazur, 2014: 251-267; Plekh, 2019: 258-272; Degtyarev, Polyakova, 2019: 83-92; Magomedov, Bagov, Zolkin, 2020: 553-558).

В рамках данной темы произведен существенный задел и красноярскими историками (Dement'ev, 2020: 55-62; Kovalev, 2019: 126-136; Konovalova, 2020: 312; Sorokun, 2019: 16-18; Malyutina, Gergilev, Gryaznukhin, Zhabaeva, 2019: 1429-1438; Elteko, Karchaeva, 2019: 137-141). Например, автором данной статьи уже рассмотрен вопрос участия женщин в органах советской власти в Сибири с 1921 по 1936 г., реконструированы условия предоставления привилегий по службе в Сибири в период первых десятилетий советской власти, сделан вклад в характеристику источников по теме кадрового состава местных Советов и их Исполнительных комитетов (Karchaevab, 2020: 95-102; Karchaeva ${ }^{a}$, 2020: 90-99; Karchaeva ${ }^{c,}$ 2020: 49-56; Karchaeva, Kizhner, Gergilev, 2020: 34-54; Dolidovich, Karchaeva, 2020: 129-137).

Цель данной статьи - выявить характерные черты и особенности социокультурного облика советских служащих низового аппарата государственного управления на территории Восточной Сибири в первое десятилетие советской власти.

Актуальность исследования подтверждена необходимостью анализа опыта управления в контексте российской истории. Кадровый вопрос в условиях социалистического государства в первые годы советской власти был вопросом воспитания нового человека - «бойца и творца светлой радостной жизни». С новыми кадрами хозяйственников и администраторов под руководством ленинско-сталинской партии Россия должна была превратиться в передовую страну, которая могла бы быть, как считали общественно-политические деятели 1920-х гг., индустриальной крепостью социализма (Vasil'ev, 1936: 3).

\section{Концептологические}

\section{основания исследования}

Основополагающая обобщающая концепция исследования - это модернизационный подход, рассматривающий явления и процессы в истории России 1920-х гг. с позиции поступательной динамики развития советского общества, перехода от аграрной организации общества к индустриальному. Данная методология апробирована научными центрами Уральского отделения Российской академии наук (Екатеринбург), Института истории Сибирского отделения Российской академии наук (Новосибирск), учеными Сибирского федерального университета (Красноярск) (Alekseev, Alekseeva, Bogatyreva, Dashkevich, Ermakova, Zubkov, Kazakova-Apkarimova, Korepanov, Kurlaev, Mikitiuk, Neklyudov, Nefedov, Nechaeva, Poberezhnikov, P'yankov, Rukosuev, Tulisov, 2016: 22-27; Mathanova, 2020: 65-71; Koptseva, 2020: 834-837).

Оригинальность исследования заключается в установлении роли кадрового состава советских управленцев в реализации управленческих функций советской власти на примере Восточной Сибири 1920-х гг. Следовательно, в статье предпринята попытка рассмотреть кадровый состав акторов модернизации. При этом автор статьи не дает оценку системы государственного и общественного управления Советской России, которая взята за данность того времени.

\section{Постановка проблемы}

Объект исследования - низовой аппарат государственного управления в советском обществе. Он рассмотрен через характеристику действовавшей системы сельских Советов, их исполнительных комитетов и анализ участников (акторов) советской власти, то есть через установление общего и особенного в человеке, причастного к системе советского управления. Следовательно, объектом исследования являются председатели, секретари, члены сельских Советов (Сельсоветов), волостных Исполнительных комитетов (Волисполкомов). Заметим, в данной статье не рассматриваются депутаты и служащие городских Советов, которые функционировали по иным нормативным положениям и требованиям.

Предмет исследования - социокультурный облик советского управленца, то есть 
советского служащего, находившегося на административной должности в сельских Советах и Волисполкомах. Характеристика социокультурного облика советских управленцев проведена по следующим критериям: пол, уровень образования, принадлежность к ВКП(б), основной вид занятости (сельское хозяйство, промышленность, сфера услуг).

Хронологические рамки исследования - 1921-1925 гг. - включают начальный период строительства советской системы управления после окончания Гражданской войны и до реформы районирования в Сибири. Территориальные границы исследования обусловлены действующей системой административно-территориального деления, поскольку Енисейская и Иркутская губернии представляли собой регионы восточной части Сибири с преобладанием в своем составе русского населения, следовательно, имели классическую модель советского управления.

Исторические источники исследования - материалы официальной статистики первой половины 1920-х гг. Это сводки сведений о выборах в Советы РСФСР (за 1923 г.), а также статистические отчеты о результатах выборных кампаний в Советы по Енисейской и Иркутской губерниям. Представленные данные репрезентативны, собраны Народным комиссариатом внутренних дел РСФР в первой половине 1920х гг., хранятся в одноименном фонде (Р-393 «НКВД РСФСР») Государственного архива Российской Федерации (далее - ГАРФ).

\section{Методология}

Методологическая основа работы базируется на антропологическом подходе и ключевых инструментах антропологически ориентированной истории. Междисциплинарность подхода обуславливает использование методов исторической науки, а также социальных и гуманитарных наук.

В основе исследования - метод историзма, с помощью которого дана характеристика структуры советских органов власти и реконструирован социокультурный об- лик государственных служащих в исторических условиях Сибири 1920-х гг.

Системный анализ позволил выявить в кадровом составе низового аппарата управления общие черты через индивидуальные примеры, а также рассмотреть единичное через общее. Идеографический подход дал возможность изучить частные случаи реализации идей советского управления на местах, а номотетический подход - осуществить в этом поиск общих закономерностей.

\section{Результаты}

\section{Характеристика системы}

низовых органов государственной власти на территории Восточной Сибири

в первой половине 1920-х г2.

Согласно конституционному строю Советской России население участвовало в государственном управлении через сформированные по территориальному признаку Советы - представительные органы власти, периодически собираемые для принятия важных решений. При этом исполнительно-распорядительную деятельность Советов осуществляли ими формируемые Исполнительные комитеты (также - исполкомы) - постоянно действующие органы власти, имеющие отраслевую структуру и подконтрольные вышестоящим исполкомам, а на центральном уровне власти подконтрольные соответствующим по направлению деятельности Народным комиссариатам (Vladimirskij, 1919: 53). Данные принципы организации советской власти представляли собой основы государственного строя, были приняты Конституцией РСФСР 1918 г., не менялись с принятием последующих Конституций СССР 1924, 1936, 1977 гг. (соответственно, Конституций РСФСР 1925, 1937, 1978 гг.).

В рассматриваемый хронологический период, в 1921-1925 гг., нижней ступенью советской системы управления были сельские Советы (Сельсоветы), при которых функционировали волостные исполкомы (Волисполкомы), исполнявшие административную работу по нескольким Сель- 
Tat'iana G. Karchaeva. Socio-Cultural Appearance of Employees of the Lower Soviet Administrative Apparatus...

Таблица 1. Количество сельских Советов на территории Восточной Сибири, 1923 г.*

Table 1. The number of village councils in the territory of Eastern Siberia, 1923

\begin{tabular}{|c|c|c|c|}
\hline \multicolumn{2}{|c|}{ Енисейская губерния } & \multicolumn{2}{|c|}{ Иркутская губерния } \\
\hline Уезд & Сельсоветы, ед. & Уезд & Сельсоветы, ед. \\
\hline Ачинский & 275 & Балаганский & 54 \\
\hline Енисейский & 51 & Селенгинский & 99 \\
\hline Канский & 394 & Киренский & 62 \\
\hline Красноярский & 308 & Зиминский & 53 \\
\hline Минусинский & 324 & Верхоленский & 92 \\
\hline \multirow{2}{*}{ Туруханский } & \multirow{2}{*}{5} & Иркутский & Тулунский \\
\cline { 2 - 4 }
\end{tabular}

* ГАРФ. Ф. 393, оп. 40, д. 7, л. 98; д. 8, л. 31.

советам. Для управления делами волости примерно один раз в месяц собирался волостной Съезд Советов, который формировался из выбранных делегатов из числа депутатов Сельсоветов данной волости.

Согласно статистическим отчетам за 1923 г. о результатах выборной кампании в Советы по Енисейской и Иркутской губерниям, на территории Восточной Сибири советская система управления была выстроена в соответствии с установленными Конституцией требованиями (табл. 1).

Сводка сведений о выборах по Енисейской губернии сообщает следующее:

- на один сельский Совет приходилось 1,9 селения, 782 жителя, 4,5 члена сельских Советов;

- на один волостной Исполнительный комитет (ВИК) или Съезд приходилось девять Сельсоветов, 41,3 члена Сельсоветов;

- на один волостной Съезд - 19,3 делегата; на одного делегата волсъезда - 365 человек населения;

- на одно селение - 404 жителя;

- на одну волость - 7071 житель.

При этом статистическая информация в Енисейской губернии была собрана по пяти уездам из шести (Ачинскому, Енисейскому, Канскому, Красноярскому, Минусинскому), в них волостей было всего 150, из которых 149 предоставили сведения ${ }^{1}$.

В сводке сведений о выборах по Иркутской губернии за 1923 г., собираемой

ГАРФ. Ф. 393, оп. 40, д. 8 , л. 149.
Народным комиссариатом внутренних дел (НКВД РСФСР), не сообщалось информации о количестве селений, жителей и членов Сельсоветов на один Сельсовет. В Москву сведения по Иркутской губернии были поданы по семи уездам из девяти (Тулунскому, Киренскому, Иркутскому, Зиминскому, Верхоленскому, Селенгинскому, Балаганскому), а в них по 82 волостям из 86 имевшихся:

- на один волостной Съезд приходилось 13,1 делегата; на одного делегата Волсъезда - 521 человек населения / жителей;

- на один волостной Исполнительный комитет (ВИК) - 32,0 членов Сельсоветов;

- на одно селение - 256 жителей;

- на одну волость - 6839 жителей ${ }^{2}$.

После реализации административнотерриториальной реформы районирования было ликвидировано губернское, уездное и волостное деление. Его сменила система округов и районов. В Енисейской губернии это произошло летом 1925 г., в Иркутской губернии - летом 1926 г. (Timoshenko, 2004: 26-29).

\section{Социокультурный облик служащих}

волостных исполнительных комитетов

\section{в Енисейской и Иркутской губерниях}

Статистические сведения о кадровом составе волисполкомов в первой половине 1920 -х гг. представлены в бюллетенях Статистического бюро НКВД о выборах в Со-

2 ГАРФ. Ф. 393, оп. 40, д. 8, л. 151. 
Tat'iana G. Karchaeva. Socio-Cultural Appearance of Employees of the Lower Soviet Administrative Apparatus...

Таблица 2. Состав членов волостных исполкомов по губерниям Восточной Сибири, 1923 г.*

Table 2. Composition of members of volost executive committees by provinces Eastern Siberia, 1923

\begin{tabular}{|c|c|c|c|c|c|c|c|c|c|c|c|c|}
\hline \multirow[b]{3}{*}{ Уезд } & \multicolumn{12}{|c|}{ Волисполкомы } \\
\hline & \multirow{2}{*}{ 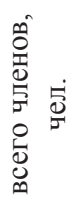 } & \multicolumn{2}{|c|}{ коммунисты } & \multicolumn{2}{|c|}{ пол } & \multicolumn{3}{|c|}{ главное занятие } & \multicolumn{4}{|c|}{ образование } \\
\hline & & $\underset{\sigma}{\stackrel{S}{S}}$ & $\partial^{\circ}$ & $\stackrel{\dot{z}}{\stackrel{\Sigma}{\Sigma}}$ & $\begin{array}{l}\dot{\Phi} \\
\text { ¿ }\end{array}$ & 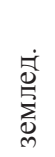 & 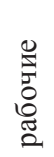 & 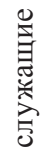 & 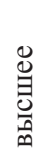 & 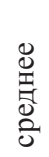 & 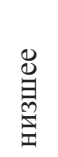 & 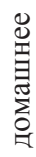 \\
\hline \multicolumn{13}{|c|}{ Иркутская губерния } \\
\hline Киренский & 36 & 7 & 19,4 & 36 & 0 & 35 & 1 & 0 & \multicolumn{3}{|c|}{36} & 0 \\
\hline Балаганский & 18 & 12 & 66,7 & 18 & 0 & 16 & 1 & 1 & \multicolumn{3}{|c|}{18} & 0 \\
\hline Селенгинский & 24 & 10 & 41,7 & 23 & 1 & 21 & 2 & 1 & \multicolumn{3}{|c|}{24} & 0 \\
\hline Зиминский & 42 & 18 & 42,9 & 42 & 0 & 39 & 2 & 1 & \multicolumn{3}{|c|}{42} & 0 \\
\hline Верхоленский & 24 & 11 & 45,8 & 24 & 0 & 20 & 4 & 0 & \multicolumn{3}{|c|}{23} & 1 \\
\hline Тулунский & 48 & 20 & 41,7 & 47 & 1 & 40 & 4 & 4 & \multicolumn{3}{|c|}{48} & 0 \\
\hline Иркутский & 54 & 23 & 42,6 & 53 & 1 & 38 & 13 & 3 & \multicolumn{3}{|c|}{54} & 0 \\
\hline \multicolumn{13}{|c|}{ Енисейская губерния } \\
\hline Канский & 123 & 99 & 80,6 & 123 & 0 & 106 & 11 & 6 & 1 & 85 & 37 & 0 \\
\hline Минусинский & 111 & 97 & 87,4 & 111 & 0 & 98 & 9 & 4 & 6 & 93 & 12 & 0 \\
\hline Енисейский & 30 & 18 & 60,0 & 30 & 0 & 18 & 9 & 3 & 0 & 17 & 12 & 1 \\
\hline Ачинский & 93 & 55 & 59,1 & 93 & 0 & 82 & 8 & 3 & 0 & 28 & 65 & 0 \\
\hline Туруханский & 9 & 3 & 33,3 & 9 & 0 & 5 & 0 & 4 & 1 & 3 & 5 & 0 \\
\hline Красноярский & 90 & 58 & 64,4 & 90 & 0 & 69 & 8 & 13 & 3 & 81 & 5 & 1 \\
\hline
\end{tabular}

* ГАРФ. Ф. Р-393, оп. 40, д. 5, л. 2, 6, 14, 17, 20-22; д. 7, л. 103, 123.

веты по территориям РСФСР и сводках сведений о выборах по уездам. Данные содержат информацию об общем количестве и социальном составе членов Волисполкомов по уездам Енисейской и Иркутской губерний․․ Показателями для анализа служат следующие критерии: принадлежность к ВКП(б), пол, основной вид занятости (сельское хозяйство, промышленность, сфера услуг), уровень образования (табл. 2).

По данным табл. 2, состав служащих Волисполкомов Иркутской и Енисейской губерний за 1923 г. был представлен только мужчинами (по одной женщине в Волисполкомах Тулунского и Иркутского уездов). Они преимущественно имели среднее и начальное («низшее») образование, работали в сельском хозяйстве. Волисполкомы в Красноярском и Иркутском уездах, центром которых были губернские города

\footnotetext{
1 ГАРФ. Ф. Р-393, оп. 40, д. 5, л. 2, 6, 14, 17, 20-22.
}

(Красноярск и Иркутск), по социокультурному составу служащих имели «лучшие» показатели. Так, в Иркутском и Красноярском уездах в составе Волисполкомов отмечалось большее число коммунистов, представителей рабочих профессий (не крестьян) и служащих, а на примере Енисейской губернии, представившей подробные сведения, - еще и более высокий уровень образования ${ }^{2}$.

\section{Социокультурный облик членов сельских Советов в Енисейской и Иркутской губерниях}

Статистические сведения о социальном составе членов сельских Советов Восточной Сибири представлены в сводках сведений о выборах в Советы.

Архивные материалы свидетельствуют, что члены сельских Советов Енисей-

\footnotetext{
2 ГА РФ. Ф. Р-393, оп. 40, д. 5, л. 20.
} 
Tat'iana G. Karchaeva. Socio-Cultural Appearance of Employees of the Lower Soviet Administrative Apparatus...

Таблица 3. Уровень образования и партийная принадлежность членов сельских Советов по губерниям Восточной Сибири, 1923 г.*

Table 3. The level of education and party affiliation of the members of the rural councils for the provinces of Eastern Siberia, 1923

\begin{tabular}{|c|c|c|c|c|c|c|c|c|}
\hline \multicolumn{9}{|c|}{ Енисейская губерния } \\
\hline \multirow{2}{*}{$\begin{array}{c}\text { Наименование } \\
\text { уезда }\end{array}$} & \multirow{2}{*}{$\begin{array}{c}\text { Число } \\
\text { членов }\end{array}$} & \multicolumn{3}{|c|}{ Образование } & \multirow{2}{*}{$\begin{array}{l}\text { Негра- } \\
\text { мотные }\end{array}$} & \multirow{2}{*}{$\begin{array}{c}\text { Комму- } \\
\text { нисты }\end{array}$} & \multirow{2}{*}{$\begin{array}{c}\text { Члены } \\
\text { других } \\
\text { партий }\end{array}$} & \multirow[b]{2}{*}{ Беспартийные } \\
\hline & & $\begin{array}{c}\text { высшее } \\
\text { и среднее } \\
\end{array}$ & низшее & домашнее & & & & \\
\hline Ачинский & 1197 & нет & 177 & 826 & 194 & 77 & нет & 1120 \\
\hline Енисейский & 255 & нет & 85 & 94 & 76 & 9 & нет & 246 \\
\hline Канский & 1684 & 2 & 568 & 956 & 158 & 215 & нет & 1469 \\
\hline Красноярский & 1424 & нет & 965 & 190 & 269 & 139 & нет & 1285 \\
\hline Минусинский & 1607 & 2 & 918 & 460 & 227 & 241 & нет & 1366 \\
\hline Туруханский & 15 & нет & 9 & 6 & нет & 4 & нет & 11 \\
\hline \multicolumn{9}{|c|}{ Иркутская губерния } \\
\hline Киренский & 290 & & 219 & & 71 & 14 & нет & 276 \\
\hline Балаганский & 156 & \multicolumn{3}{|c|}{142} & 14 & 12 & нет & 144 \\
\hline Селенгинский & 245 & \multicolumn{3}{|c|}{213} & 32 & 13 & нет & 232 \\
\hline Зиминский & 441 & \multicolumn{3}{|c|}{408} & 33 & 48 & нет & 393 \\
\hline Верхоленский & 289 & \multicolumn{3}{|c|}{246} & 43 & 30 & нет & 259 \\
\hline Тулунский & 609 & \multicolumn{3}{|c|}{456} & 153 & 51 & нет & 558 \\
\hline Иркутский & 555 & \multicolumn{3}{|c|}{486} & 69 & 51 & нет & 504 \\
\hline
\end{tabular}

* ГАРФ. Ф. 393, оп. 40, д. 7, л. 98, 123-129.

ской губернии в первые годы советской власти не имели достаточного уровня профессиональной подготовки для реализации местного управления (табл. 3).

Данные табл. 3 указывают, что сельские Советы Енисейской губернии были представлены избранными лицами, в основном имевшими низшее (начальное) или домашнее образование: в Ачинском уезде - 14,7 и 69 \% соответственно, Енисейском - 36,8 и 33,3 \%, Канском 33,7 и $56,7 \%$, Красноярском уезде - 13 и $67,7 \%$, Минусинском уезде - 57,1 и $28,6 \%$. При этом низшее (начальное) образование было по качеству «лучшим» по сравнению с домашним образованием, заключавшимся, как правило, в умениях читать, писать и считать. Имевших высшее или среднее образование (университет, институт, гимназия и др.) было только 4 чел., и их наличие представляло собой скорее исключение. Количество неграмотных членов сельских Советов в Енисейской губернии варьировалось в пределах 16-29\%. При этом в Иркутской губернии избранных в систему местной власти из числа неграмотных сельчан было меньше - от 10 до $26 \%$.

В свою очередь, члены сельских Советов как в Иркутской, так и Енисейской губернии в первые годы советской власти не владели основами марксистсколенинской теории, так как по результатам избирательной кампании на 1923 г. в среднем около 90 \% членов сельских Советов были беспартийными. Следовательно, им было не под силу организовать массы на выполнение директив партии, исполнять ее поручения.

Социокультурный облик членов сельских Советов Енисейской и Иркутской губерний необходимо рассмотреть по половой принадлежности (мужчины или женщины) и критерию основного вида заня- 
Tat'iana G. Karchaeva. Socio-Cultural Appearance of Employees of the Lower Soviet Administrative Apparatus...

Таблица 4. Состав членов сельских Советов по губерниям Восточной Сибири, 1923 г.*

Table 4. Composition of members of rural councils for provinces Eastern Siberia, 1923

\begin{tabular}{|c|c|c|c|c|c|c|}
\hline \multicolumn{7}{|c|}{ Енисейская губерния } \\
\hline $\begin{array}{c}\text { Наименование } \\
\text { уезда }\end{array}$ & $\begin{array}{c}\text { Число } \\
\text { членов }\end{array}$ & Мужчины & Женщины & Земледельцы & Рабочие & Служащие \\
\hline Ачинский уезд & 1197 & 1178 & 19 & 1193 & 4 & нет \\
\hline Енисейский уезд & 255 & 253 & 2 & 236 & 16 & 3 \\
\hline Канский уезд & 1684 & 1680 & 4 & 1611 & 48 & 25 \\
\hline Красноярский уезд & 1424 & 1422 & 2 & 1398 & 15 & 11 \\
\hline Минусинский уезд & 1607 & 1583 & 24 & 1547 & 49 & 11 \\
\hline Туруханский край & 15 & 15 & нет & $\begin{array}{c}\text { промысловики - } \\
14\end{array}$ & 1 & нет \\
\hline \multicolumn{7}{|c|}{ Иркутская губерния } \\
\hline Киренский & 290 & 285 & 5 & 286 & 3 & 1 \\
\hline Балаганский & 156 & 154 & 2 & 154 & 1 & 1 \\
\hline Селенгинский & 245 & 242 & 3 & 233 & 9 & 3 \\
\hline Зиминский & 441 & 440 & 1 & 421 & 10 & 10 \\
\hline Верхоленский & 289 & 289 & нет & 279 & 8 & 2 \\
\hline Тулунский & 609 & 605 & 4 & 594 & 8 & 7 \\
\hline Иркутский & 555 & 537 & 18 & 495 & 46 & 14 \\
\hline
\end{tabular}

* ГАРФ. Ф. 393, оп. 40, д. 7, л. 98, 123-129.

тости (земледельцы, рабочие и служащие) (табл. 4).

Анализ данных табл. 4 показал, что кадровый состав сельских Советов Енисейской и Иркутской губерний был представлен выходцами из крестьянской среды - более 90 \%. Данный факт объяснялся основным занятием населения в сельской местности и преимущественным выбором сельчанами на должности депутатов сельских Советов именно односельчан. Уникальным в этом отношении представляется Туруханский край, жители которого были промысловики, то есть рыбаки и охотники.

Таблица 4 дает информацию о реализации идей равенства мужчин и женщин во власти, так как согласно советскому законодательству женщинам была предоставлена возможность для работы в аппарате управления. Однако количество избранных женщин в сельские Советы в Енисейской и Иркутской губерниях было не более $3 \%$. Через 10 лет (в 1933 г.) И.В. Сталин на I Съезде колхозников-ударников ука- зал на отсутствие должного числа женщин в системе государственного управления, заявив, что женщины - это большая сила, которую нужно выдвигать вперед, в систему советского управления (Сталин И. В. Вопросы ленинизма, 10-е изд., с. 534). Выдвижению женщин-руководителей в селе, как и в городе, препятствовали утвержденные временем социальные нормы, согласно которым существовало разделение мужских и женских ролей, а в число последних не входила сфера власти.

Интересным является факт присутствия в первой половине 1920-х гг. в числе председателей и секретарей сельских Советов по Енисейской и Иркутской губерниям около $60 \%$ лиц, имевших военный опыт службы в Красной армии, «партизанщине», реже - в Царской или Белой армии, или сразу в нескольких по очередности. Анализ анкет, опросных листов и регистрационных карточек председателей и секретарей сельских Советов также показал, что это были мужчины среднего возраста. Выбор на должности 
председателя и секретаря сельского Совета мужчин с наличием военного опыта объяснялся уважительным отношением к ним со стороны односельчан, а средний возраст (30-50 лет) большинства председателей и секретарей Сельсоветов обуславливал факт их призыва по возрасту в 1914-1917 гг. Кроме того, на данные должности избирались, как правило, люди с активной гражданской позицией, которые в условиях Гражданской войны не могли оставаться безучастными к происходящему вокруг. При этом прочие их социальные характеристики не отличались от общего социокультурного облика членов сельских Советов.

\section{Выводы}

По государственному проекту социалистического строительства руководители и служащие местных органов пролетарской диктатуры должны были быть мужчинами и женщинами, всесторонне развитыми, культурными деятелями, владевшими основами марксистско-ленинской теории. Однако анализ архивных материалов показал, что Советы и Исполнительные комитеты низового уровня управления Восточной Сибири в первой половине 1920-х гг. были укомплектованы лицами с низшим уровнем образования, почти или совсем неграмот- ными, по основному виду деятельности крестьянами (хлебопашцами), по партийной принадлежности - беспартийными. Несмотря на провозглашенное гендерное равенство, женщины, причастные к управлению, почти отсутствовали. Важно, что на тот момент, в первой половине 1920-х гг., государство еще характеризовалось лояльным отношением к военному «сомнительному» и даже «белогвардейскому» прошлому председателей и секретарей сельских Советов, избираемых сельчанами на руководящие должности.

Таким образом, социокультурный облик государственных служащих низового «соваппарата», представленный в статье на основе централизованной статистики, отличался от должного уровня. Члены волостных Исполнительных комитетов, члены (депутаты) сельских Советов, среди которых были председатели и секретари сельских Советов, вряд ли имели широкий кругозор и умение организовать массы на выполнение директив большевистской партии и советского правительства. Разумеется, они могли исполнять и исполняли поручения сверху, но не могли разумно судить о каждом явлении или факте местной жизни со стороны общегосударственных задач.

\section{Список литературы / References}

Alekseev, V.V., Alekseeva, E.V., Bogatyreva, O.N., Dashkevich, L.A., Ermakova, O.K., Zubkov, K.I., Kazakova-Apkarimova, E.IU., Korepanov, N.S., Kurlaev, E.A., Mikitiuk, V. P., Neklyudov, E.G., Nefedov, S.A., Nechaeva, M. IU., Poberezhnikov, I.V, P’yankov, S.A., Rukosuev, E.IU., Tulisov, E.S. (2016). Aktory rossijskoj imperskoj modernizatsii (XVIII - nachalo XX v.): regional'noe izmerenie [Actors of the Russian Imperial modernization (XVIII-early XX century): regional dimension]. Ekaterinburg, Institut istorii i arkheologii UrO RAN, Bank kul'turnol̆ informat sii, 316 p.

Cook, L. (2013). Collegiality in the People's Commissariats, 1917-1920, In Revolutionary Russia, 26 (1), 1-31.

Dameshek, L.M., Dameshek, I.L. (2020). Istoriya politsii Aziatskoj Rossii v novejshikh sibirevedcheskikh issledovaniyakh [The history of the police in Asian Russia in the latest Siberian research], In Izvestiya irkutskogo gosudarstvennogo universiteta». Seriya «Istoriya» [The bulletin of Irkutsk State University], 33, 103-107. DOI: 10.26516/2222-9124.2020.33.103

Degtyarev, S.I., Polyakova, L.G. (2019). Orphan Courts in the System of State Institutions of the Russian Empire of the End of the XVIII - 60s of the XIX centuries: Personal Composition, Competence, Rights and Duties of Guardians, In Bylye Gody, 51 (1), 83-92. DOI: 10.13187/bg. 2019.1. 83

Dement'ev, A.P. (2020). Partijnye organizatsii eserov i men'shevikov Enisejskoj gubernii v usloviyakh Grazhdanskoj vojny (iiun' 1918 - ianvar' 1920 g.) [Political party associations of socialists-revolutionaries 
and mensheviks in Yeniseysk Governorate under the conditions of Civil War (June 1918 - January 1920], In Severnye Arkhivy i Ekspeditsii [Northern Archives and Expeditions], 4 (2), 55-62. DOI: 10.31806/25421158-2020-4-2-55-62

Dolidovich, O.M., Karchaeva, T.G. (2020). Politicheskâi a mobilizat siî a zhenshchin v 1920-kh gg. (na materialakh Eniseřskoĭ gubernii) [Political mobilization of women in the 1920s (On materials of the Yenisei province)], In Zhenshchina v rossiǔskom obshchestve [Woman in Russian Society], 2, 129-137. DOI: 10.21064/WinRS.2020.2.11

Dyatlov, V.I., Dyatlova, E.V. (2020). From the «Influx of the Yellow Race» to «Migrant Workers»: Dynamics of the Languagesfor Describing Cross-Border Migrations in Russia, In Journal of Siberian Federal University. Humanities and Social Sciences, 13 (5), 623-638. DOI: 10.17516/1997-1370-0594

Elteko IU.V., Karchaeva T. G. (2019). Organizaciya izbiratel'nyh kampanij v sel'skie sovety Vostochnoj Sibiri v nachale 1920-h godov (na materialah Enisejskoj gubernii) [Organization of election campaigns in the village Councils of Eastern Siberia in the early 1920 s (on materials of the Yenisei Province)], In Problemy social'no-ekonomicheskogo razvitiya Sibiri [Issues of Social-Economic Development of Siberia], 1 (35), 137-141.

Hahn, J.W. (1988). Soviet Grassroots: Citizen Participation in Local Soviet Government. London, I. B. Tauris \& Co Ltd Publishers, 320 p.

Karchaeva T. G., Kizhner I. A., Gergilev D. N. (2020). Participation of Women in Local and Regional Soviets in Eastern Siberia from 1921 to 1936: Statistical Sources Analysis, In Historical informatics, 1, 34-54. DOI: 10.7256/2585-7797.2020.1.32080

Karchaeva, T.G. ${ }^{a}$ (2020). Dokumenty fonda «Ispolkom krasnoyarskogo gorsoveta (gorispolkom)» Gosudarstvennogo arhiva Krasnoyarskogo kraya o kadrovom sostave sovetskih upravlencev Sibiri v 19261936-e gg. [Documents of the fund «Executive Committee of the Krasnoyarsk City Council (City Executive Committee)» of the State Archive of the Krasnoyarsk Territory about the personnel of Soviet managers of Siberia from 1926 to 1936], In Severnye Arkhivy i Ekspeditsii [Northern Archives and Expeditions], 4 (2), 90-99. DOI: 10.31806/2542-1158-2020-4-2-90-99

Karchaeva, T.G. ${ }^{\text {b }}$ (2020). Dokumenty fonda «Narodnyj komissariat vnutrennih del RSFSR» Gosudarstvennogo arhiva Rossijskoj Federacii o kadrovom sostave volostnyh ispolnitel'nyh komitetov Vostochnoj Sibiri v pervoj polovine1920-h gg. [The data on personnel of the volost Executive Committees in East Siberia during first half 1920s from archival data People's Commissariat for Internal Affairs of the State Archive of the Russian Federation], In Izvestiya irkutskogo gosudarstvennogo universiteta». Seriya "Istoriya» [The bulletin of Irkutsk State University], 33, 95-102. DOI: 10.26516/2222-9124.2020.33.95

Karchaeva, T.G. ' (2020). Dokumenty Nacional'nogo arhiva Respubliki Hakasiya ob uchastii ispolkomov mestnyh Sovetov v registracii imushchestvennyh sdelok i soglashenij naseleniya v 1923-1934 gg. ( $\mathrm{k}$ istorii notariata $\mathrm{v}$ Sibiri) [Documents of the National Archive of the Republic of Khakassia about the participation of Executive Committees of local Soviets in the registration of population's agreements from 1923 to 1934 (to the history of Notaries in Siberia], In Severnye Arkhivy i Ekspeditsii [Northern Archives and Expeditions], 4 (3), 49-56. DOI: 10.31806/2542-1158-2020-4-3-49-56

Kazarin, V.N. (2020). Vlast' i gorodskoj sotsium Irkutskoj gubernii v modernizatsionnykh protsessakh XIX - nachala XX v. [Authority and city society of Irkutsk province in the modern processes of the XIX - beginning XX century], In Izvestiya irkutskogo gosudarstvennogo universiteta». Seriya «Istoriya» [The bulletin of Irkutsk State University], 31, 101-106. DOI: 10.26516/2222-9124.2020.31.101

Konovalova. O.V. (2020). Razvitie pravoohranitel'nyh organov Rossii v IX-nachale XX vekov [Development of law enforcement agencies in Russia in the IX-early XX centuries]. Krasnoyarsk, Sibirskij yuridicheskij institut MVD RF, $312 \mathrm{p}$.

Koptseva, N.P. (2020). Introduction to the Thematic Issueof the Siberian Federal University Journal, the Humanities Series, in the «History And Theory Of Art» Research Field, In Journal of Siberian Federal University. Humanities and Social Sciences, 13 (6), 834-837.

Kovalev, A.S. (2019). Netrudosposobnye zhenshchiny v fokuse gosudarstvennoj social'noj politiki 1920-1930-h gg. (na materialah Sibiri) [Disabled women and Soviet Social Policy in 1920-1930s (based 
on the siberia related research)], In Zhenshchina v rossiuskom obshchestve [Woman in Russian Society], 4, 126-136. DOI: 10.21064/WinRS.2019.4.11

Magomedov, I.A., Bagov, A.M., Zolkin, A.L. (2020). Internet of Things: Future Business, In European Proceedings of Social and Behavioural Sciences EpSBS. Krasnoyarsk Science and Technology City Hall. Krasnoyarsk, 2020, 553-558.

Malyutina, L.F., Gergilev, D.N., Gryaznukhin, A.G., Zhabaeva, L.B. (2019). Social Thought in Russia of Its Czarist-Era about the Place of Siberia in the State Structure of the Country, In Bylye Gody, 54 (4), 1429-1438. DOI: 10.13187/bg.2019.4.1429

Mathanova, N.P. (2020). Habarovskie s»ezdy «svedushchih lyudej» i priamurskij general-gubernator A. N. Korf: poiski kanalov kommunikacii mezhdu vlast'yu i obshchestvom v Imperskoj Rossii [Meetings of «Well-Informed People» in Khabarovsk and the Priamur Governor-General A. N. Korf: searching of communication channels between the authority and society in Imperial Russia], In Gumanitarnye nauki v Sibiri [Humanitarian sciences in Siberia], 27 (3), 65-71. DOI: 10.15372/HSS20200311

Mazur, L.N. (2014). Stanovlenie i evolyuciya sel'skoj byurokratii v Rossii vo vtoroj polovine XIX - nachale XX v. [The emergence and evolution of rural bureaucracy in Russia in the 2nd half of the 19th - early 20th century]. In Izvestiya Ural'skogo Federal'nogo Universiteta. Seriya 2: Gumanitarnye Nauki [Izvestia. Ural Federal University Journal. Series 2. Humanities and Arts], 2 (127), 251-267.

Plekh, O.A. (2019). Provincial'noe chinovnichestvo Rossii v pervoj polovine XIX v.: otechestvennaya istoriografiya konca XX - nachala XXI v. [Provincial bureaucracy of Russia in the first half of the XIX century: domestic historiography of the end of the XX - early XXI century], In Voprosy istorii [Issues of History], 11, 258-272. DOI: 10.31166/VoprosyIstorii201911Statyi04

Rittersporn, G.T. (1984). Soviet officialdom and political evolution, In Theory and Society, 13 (2), 211-237, available at: http://www.jstor.org/stable/657362

Rowney, D., Huskey, E. (2009). Russian bureaucracy and the state: officialdom from Alexander III to Vladimir Putin. New York, Palgrave Macmillan, 346 p.

Sorokun, P.V. (2019). Sovetskii kadrovyi sostav Krasnoyarskogo okruga Sibirskogo kraya vo vtoroi polovine 20-kh gg. XX veka [The Soviet Personnel Structure of the Krasnoyarsk District of Siberia in the second half of 20 of the XX centuries], In Epokha nauki [Age of Science], 17, 16-18. DOI: 10.24411/24093203-2018-11704

Stalin, I. V. (1939). Voprosy leninizma [Questions of Leninism]. Moskva, 445 p.

Timoshenko, A.I. (2004). Proekty ekonomicheskogo i administrativno-territorial'nogo deleniya sibirskogo regiona v 1920-e gg. [The projects of economic, and administrative and territorial divisions of Siberia in 1920s], In Gumanitarnye nauki v Sibiri [Humanitarian sciences in Siberia], 2, $26-29$.

Vasil'ev, V.V. (1936). Rastut novye sovetskie kadry [New Soviet cadres are growing]. Leningrad, Izdatel'stvo Lenoblispokoma i Lensoveta, $64 \mathrm{p}$.

Vladimirov, V.N., Sarafanov, D.E., SHCHetinina, A.S. (2019). Traditsionnaya i novaya istoricheskaya demografiya: vzglyad spetsialistov [Traditional and new historical demography: an expert view], In Vestnik Tomskogo gosudarstvennogo universiteta [Tomsk State University Journals], 443, 99-105. DOI: $10.17223 / 15617793 / 443 / 13$

Vladimirskij, M.F. (1919). Organizatsiya sovetskoj vlasti na mestakh [Organization of Soviet power in the field]. Moskva, Gosudarstvennoe izdatel'stvo, $146 \mathrm{p}$. 